\title{
Perbedaan penerapan model pembelajaran Project Based Learning dan model pembelajaran Kooperatif Tipe Think Pair Share (TPS) berbantuan modul ajar terhadap motivasi dan hasil belajar siswa pada mata pelajaran kompetensi kejuruan SMKN 1 Blitar
}

\author{
Puger Honggowiyono ${ }^{1}$, Hakkun Elmunsyah ${ }^{2}$, Reni Puspita Nurfadmi ${ }^{3}$ \\ 1. Universitas Negeri Malang, Indonesia | puger@um.ac.id \\ 2. Universitas Negeri Malang, Indonesia | hakkun@um.ac.id \\ 3. Universitas Negeri Malang, Indonesia | reni.puspita.nur@gmail.com
}

\begin{abstract}
Abstrak
Tujuan dari penelitian ini adalah mengetahui perbedaan motivasi dan hasil belajar menggunakan model pembelajaran Project Based Learning dan model pembelajaran Think Pair Share (TPS) pada mata pelajaran Instalasi Penerangan Listrik 1 di SMKN 1 Blitar. Jenis penelitian yang digunakan adalah quasi experimental design atau eksperimen semu, dengan desain penelitian menggunakan simple random sampling dengan pola pretest-posttest control group design. Populasi pada penelitian ini adalah seluruh siswa kelas X TITL SMKN 1 Bltar yang berjumlah 4 kelas. Sedangkan sampel pada penelitian ini adalah kelas X TITL 3 sebagai kelas eksperimen dan kelas X TITL 1 sebagai kelas kontrol. Variabel penelitian terdiri dari variabel bebas yaitu model pembelajaran dan variabel terikat yaitu motivasi dan hasil belajar siswa pada mata pelajaran kompetensi kejuruan. Berdasarkan analisis uji-t dapat disimpulkan bahwa tidak terdapat perbedaan yang signifikan terhadap hasil belajar ranah Pengetahuan. Tetapi terdapat perbedaan yang signifikan terhadap ranah Sikap dan Ketrampilan. Kemudian untuk motivasi belajar dapat disimpulkan tidak terdapat perbedaan yang signifikan dengan menggunakan model pembelajaran Project Based Learning dan model pembelajaran kooperatif tipe Think Pair Share (TPS) pada mata pelajaran kompetensi kejuruan SMKN 1 Blitar.
\end{abstract}

Kata Kunci

Project Based Learning, Think Pair Share (TPS), Motivasi Belajar, Hasil Belajar, Kompetensi Kejuruan

TEKNO Vol. 27 Issue 2, p105-115 | Jurusan Teknik Elektro, Universitas Negeri Malang, Indonesia | September 2017

S. C. Putro, D. Lestari, H. M. F. Bela | Hubungan Antara Kenyamanan Belajar Dan Ketersediaan Sumber Belajar Dengan ... 


\section{TEKNO Jumal Teknologi, Eektro, dan Kejivruan}

http://journal2.um.ac.id/index.php/tekno | ISSN 1693-8739

\section{Pendahuluan}

Pendidikan merupakan usaha sengaja dan terencana untuk membantu meningkatkan perkembangan potensi bagi manusia agar bermanfaat bagi kepentingan hidupnya sebagai makhluk individu maupun makhluk sosial. Salah satu upaya yang dilakukan untuk mencapai keberhasilan dalam mencerdaskan anak-anak bangsa sebagaimana yang telah dirumuskan dan ditetapkan dalam Undang-Undang Sistem Pendidikan Nasional, maka penting sekali untuk membina dan mengembangkan profesional guru (BSNP, 2006). Salah satu bentuk atau wujud profesionalnya guru dalam mengajar adalah ditandai dengan kepiawaian guru tersebut memilih dan menggunakan model pembelajaran yang tepat untuk diaplikasikan pada materi ajar yang sesuai dengan materi tersebut. Jelasnya dan khususnya terkait dengan model pembelajaran bahwa guru yang profesional adalah guru yang mampu menerapkan model pembelajaran secara bervariasi pada materi ajar yang disampaikannya. Pentingnya guru menggunakan model pembelajaran ketika menyampaikan bahan ajar dikaarenakan kedudukan model pembelajaran adalah salah satu upaya untuk mencapai tujuan pembelajaran yang telah dirumuskan.

Model pembelajaran Project Based Learning merupakan model pembelajaran berbasi proyek dengan menekankan aktivitas siswa dalam memecahkan masalah (Arikunto, Suharsim, 2009). Sedangkan model pembelajaran Think Pair Share merupakan model pembelajaran kooperatif yang dirancang untuk mempengaruhi pola inetraksi siswa (Priyatno, 2012). Dari penelitian sebelumnya disimpulkan bahwa terdapat perbedaan yang signifikan antara kelompok siswa dengan model pembelajaran Project Based Learning dan Think Pair Share (TPS), didapatkan bahwa rata-rata hasil belajar kelas eksperimen lebih tinggi yaitu dengan menerapkan model pembelajaran Project Based Learning daripada kelas kontrol dengan menerapkan model pembelajaran Think Pair Share (Sanjaya, 2013). Hal ini dikarenakan PBL menuntut siswa harus memiliki ketrampilan berpikir bagaimana mengerjakan tugas tersebut dan belajar bagaimana caranya untuk memecahkan masalah pada tugas yang diberikan (Trianto, 2011)

Berdasarkan hasil observasi kelas dan keterangan guru mata pelajaran Kompetensi Kejuruan yaitu Bapak Siswandi, S.T. kelas X TITL semester genap di SMKN 1 Blitar menunjukkan bahwa materi pembelajaran yang diberikan kepada siswa kembali mengacu pada Kurikulum KTSP. Berdasarkan keterangan Pak Siswandi keterbatasan penyampaian materi juga menjadi masalah yang ada dikelas. Hal ini dikarenakan guru masih menjadi sumber utama dalam belajar. Guru pernah menerapkan metode presentasi tetapi setelah mengetahui hasilnya siswa yang aktif bisa mengikuti pembelajaran tetapi metode yang diterapkan belum dapat meningkatkan partisipasi belajar siswa yang pasif. Selain itu menurut keterangan guru, metode pembelajaran presentasi belum bisa diterapkan dalam kelas tersebut karena jika metode pembelajaran tersebut diterapkan siswa akan ramai dan hanya fokus pada tugas yang diberikan pada setiap kelompok akibatnya materi yang seharusnya dapat disampaikan semua pada siswa tidak menjadi maksimal.

TEKNO Vol. 27 Issue 2, p105-115 | Jurusan Teknik Elektro, Universitas Negeri Malang, Indonesia | September 2017

S. C. Putro, D. Lestari, H. M. F. Bela | Hubungan Antara Kenyamanan Belajar Dan Ketersediaan Sumber Belajar Dengan ... 


\section{TEKNO Jumal Teknologi, Eektro, dan Kejivruan}

http://journal2.um.ac.id/index.php/tekno | ISSN 1693-8739

Hasil belajar sebagian siswa belum mencapai KKM juga menjadi masalah yang dihadapi oleh Pak Siswandi dalam mengampu mata pelajaran tersebut. Salah satu hal yang mengakibatkan hasil belajar siswa belum mencapai KKM dikarenakan motivasi dan antusiasme siswa yang masih rendah (Rais, 2010). Siswa masuk jurusan listrik dikarenakan kemauan orang tua juga menjadi alasan bahwa motivasi siswa dalam belajar dikelas khususnya jurusan listrik menjadi kurang. Siswa merasa terpaksa belajar di jurusan listrik sehingga hasil belajar siswa juga menjadi rendah.

Dari pola pembelajaran seperti dijabarkan diatas maka diperlukan penerapan model pembelajaran yang mampu mendorong siswa untuk aktif serta meningkat-kan motivasi belajar dan dapat meningkatkan kualitas belajar pada siswa (Sardiman, 2011). Salah satu model pembelajaran yang melibatkan peran serta siswa adalah model pem-belajaran Project Based Learning (Riyanto, 2010). Model pembelajaran Project Based Learning merupakan salah satu alternatif model pembelajaran yang secara langsung melibatkan siswa dalam proses pembelajaran melalui kegiatan penelitian untuk mengerjakan dan menyelesaikan suatu proyek pembelajaran tertentu (Yunus, 2014).

Suasana belajar yang menyenangkan diindikasikan dapat membuat proses pembelajaran lebih efektif dan menumbuhkan motivasi siswa, yaitu siswa akan mampu membangun pemahamannya dengan kondisi fisik dan psikis yang tidak tertekan (Hamalik, 2014). Suasana yang menyenangkan juga akan membuat guru mampu menyampaikan materi pelajaran dengan lebih baik (Kosasih, 2014). Di samping itu siswa akan dapat menerima materi pelajaran dengan senang, sehingga apa yang disampaikan oleh guru akan lebih cepat diterima dan diingat dengan baik oleh siswa.

Berdasarkan latar belakang yang diuraikan di atas, maka dilakukan penelitian dengan judul "Perbedaan Penerapan Model Pembelajaran Project Based Learning Dan Model Pembelajaran Kooperatif Tipe Think Pair Share (TPS) Berbantuan Modul Ajar Terhadap Hasil Belajar dan Motivasi Belajar Siswa Pada Mata Pelajaran Kompetensi Kejuruan SMKN 1 Blitar"

\section{Metode}

Rancangan penelitian ini menggunakan rancangan penelitian eksperimen Quasi Experimental Design atau eksperimen semu dengan posttest control design. Dalam penelitian ini menggunakan dua kelas untuk dijadikan sampel penelitian. Satu kelas dijadikan kelas eksperimen dan satu kelas lainnya dijadikan kelas kontrol. Diantara dua kelas tersebut mendapatkan perlakuan yang sama dari segi tujuan dan materi yang diajarkan, akan tetapi antara kelas eksperimen dan kelas kontrol terdapat perbedaan dari segi model pembelajaran yang digunakan. Kelas eksperimen menggunakan model pembelajaran Project Based Learning sedangkan kelas kontrol menggunakan model pembelajaran Think Pair Share (Dimyati dan Mudjiono, 2009). Sehingga rancangan ini dimaksudkan untuk membandingkan hasil dan motivasi belajar menggunakan model pembelajaran Project Based Learning dan menggunakan model pembelajaran Think Pair Share.

TEKNO Vol. 27 Issue 2, p105-115 | Jurusan Teknik Elektro, Universitas Negeri Malang, Indonesia | September 2017

S. C. Putro, D. Lestari, H. M. F. Bela | Hubungan Antara Kenyamanan Belajar Dan Ketersediaan Sumber Belajar Dengan ... 


\section{TEKNO Jurnal Teknologi, Elektro, dan Kejuruan}

http://journal2.um.ac.id/index.php/tekno | ISSN 1693-8739

Sebelumnya siswa dari kelompok eksperimen dan kontrol diberikan pretest, yaitu test pengetahuan yang dilakukan sebelum proses pembelajaran diterapkan. Selanjutnya untuk test akhir berupa posttest pada kompetensi pengetahuan, lembar observasi untuk kompetensi sikap dan keterampilan serta angket motivasi belajar untuk mengetahui motivasi belajar siswa setelah diberi perlakuan antara kelas eksperimen menggunakan model pembelajaran Project Based Learning dan kelas kontrol menggunakan model pembelajaran Think Pair Share. Adapun rancangan penelitian yang digunakan dapat dilihat pada Tabel 1.

\begin{tabular}{lll} 
Tabel 1 Rancangan Penelitian & & \\
\hline Model Pembelajaran & Perlakuan & Post-test \\
\hline Project Based Learning & $\mathrm{X}_{1}$ & $\mathrm{O}_{1}$ \\
Think Pair Share & $\mathrm{X}_{2}$ & $\mathrm{O}_{2}$ \\
\hline
\end{tabular}

Keterangan:

$\mathrm{X} 1=$ pemberian perlakuan dengan model pembelajaran Project Based Learning

$\mathrm{X} 2=$ pemberian perlakuan dengan model pembelajaran Think Pair Share

O1 = tes kemampuan akhir (posttest)

$\mathrm{O} 2=$ tes kemampuan akhir (posttest)

Variabel penelitian ini adalah model pembelajaran Project Based Learning dan Think Pair Share (TPS) sebagai variabel bebas sedangkan hasil dan motivasi belajar sebagi variabel terikat (Lia, Nur E. R. W. 2013). Populasi penelitian ini adalah siswa kelas X SMKN 1 Blitar jurusan teknik instalasi tenaga listrik tahun ajaran 2014-2015. Sampel penelitian yang digunakan dua kelas yaitu kelas eksperimen dan kelas kontrol.

Instrumen penelitian yang digunakan yaitu instrumen perlakuan yang meliputi: (1) Silabus, (2) RPP, dan (3) Modul Pembelajaran (Sugiyono, 2013). Sedangkan instrumen pengukuran meliputi: (1) soal pretest digunakan untuk mengetahui kemampuan awal siswa dan posttest untuk mengetahui nilai akhir siswa setelah diberi perlakuan dengan bentuk soal tes sejumlah 40 soal yang sudah divalidasi, (2) angket-/kuisioner untuk mengukur motivasi siswa, dan (3) lembar observasi untuk penilaian sikap dan keterampilan (Majid, 2013).

Uji instrumen meliputi: (1) uji validitas isi untuk mengukur kevalidan soal yang dibuat terhadap ranah materi, kontruksi dan ranah bahasa yang dipakai, (2) validasi butir soal, (3) uji reabilitas tes, (4) uji tingkat kesukaran butir soal, dan (5) uji daya beda butir soal (Syah, 2013).

Teknik analisis data berupa uji prasyarat analisis yang meliputi: (1) uji normalitas yang bertujuan untuk mengetahui apakah data terdistribusi normal atau tidak, (2) uji homogenitas digunakan untuk mengetahui homogen atau tidaknya data ang dianalisi, (3) uji kesamaan dua rata-rata untuk membuktikan kemampuan awal pada kedua sampel, dan (4) uji perbedaan antara kemampuan awal dan akhir siswa (Sudjana, 2013).

Uji hipotesis digunakan untuk mengetahui apakah terdapat per-bedaan hasil belajar dari ranah pengetahuan, sikap dan keterampilan yang menggunakan analisis uji-t. 


\section{TEKNO Jurnal Teknologi, Elektro, dan Kejuruan}

http://journal2.um.ac.id/index.php/tekno | ISSN 1693-8739

\section{Hasil}

\section{a. Soal Pretest dan Posttest}

Hasil validasi isi instrumen soal pretest dan posttest diketahui rerata sebesar $86,88 \%$, $88,3 \%, 85 \%$, hal tersebut sesuai bahwa validasi isi soal untuk pretest dan posttest dapat dikategorikan dalam kriteria sangat tinggi.

\section{b. Modul Pembelajaran}

Hasil validasi instrumen modul pembelajaran diketahui rerata sebesar $93,1 \%$ dan $94,4 \%$, hal tersebut sesuai bahwa validasi modul pembelajaran dapat dikategorikan dalam kriteria sangat tinggi.

\section{c. Rencana Pelaksanaan Pembelajaran (RPP)}

Hasil validasi isi instrumen Rencana Pelaksanaan Pembelajaran (RPP) Hasil diketahui rerata sebesar 90,62\% dan 97,6\%, hal tersebut sesuai bahwa validasi Rencana Pelaksanaan Pembelajaran (RPP) dapat dikategorikan dalam kriteria sangat tinggi.

\section{d. Angket Motivasi Belajar}

Hasil validasi isi angket motivasi belajar Berdasarkan diketahui rerata sebesar $87 \%$ dan $85 \%$ hal tersebut sesuai bahwa validasi angket motivasi belajar dapat dikategorikan dalam kriteria sangat tinggi.

e. Hasil Uji Normalitas Data Pengetahuan, Sikap, Ketrampilan, dan Motivasi Belajar Hasil uji normalitas data Pengetahuan dengan One-Sample Kolmogorov-Smirnov Test meng-gunakan bantuan SPSS 16.0 for windows. Hasil data diperoleh hasil Pengetahuan memiliki nilai Asymp.Sig. 0,215 dan kelas kontrol sebesar 0,160, dimana nilai probabilitas (Asymp.sig) > 0,05. Dari hasil tersebut dapat disimpulkan bahwa data hasil belajar pengetahuan siswa kedua kelas berdistribusi normal.

Hasil uji normalitas data Sikap dengan One-Sample Kolmogorov-Smirnov Test menggunakan bantuan SPSS 16.0 for windows. Berdasarkan data diperoleh hasil Sikap nilai memiliki nilai Asymp.Sig. 0,252 dan pada kelas kontrol sebesar 0,604, dimana nilai probabilitas (Asymp.sig) > 0,05. Dari hasil tersebut dapat disimpulkan bahwa data hasil belajar sikap siswa kedua kelas berdistribusi normal.

Hasil uji normalitas data Ketrampilan dengan One-Sample Kolmogorov-Smirnov Test meng-gunakan bantuan SPSS 16.0 for windows. Hasil data diperoleh hasil Ketrampilan memiliki nilai Asymp.Sig. 0,276 dan pada kelas kontrol sebesar 0,379, dimana nilai probabilitas (Asymp.sig) > 0,05. Dari hasil tersebut dapat disimpulkan bahwa data hasil belajar ketrampilan siswa kedua kelas berdistribusi normal.

Hasil uji normalitas data motivasi belajar siswa dengan One-Sample KolmogorovSmirnov Test menggunakan bantuan SPSS 16.0 for windows. Berdasarkan data diperoleh hasil motivasi belajar memiliki nilai Asymp.Sig. 0,625 dan pada kelas kontrol sebesar 0,788, 


\section{TEKNO Jurnal Teknologi, Elektro, dan Kejuruan}

http://journal2.um.ac.id/index.php/tekno | ISSN 1693-8739

dimana nilai probabilitas (Asymp.sig) $>0,05$. Dari hasil tersebut dapat disimpulkan bahwa data hasil motivasi belajar siswa kedua kelas berdistribusi normal.

\section{f. Hasil Uji Homogenitas Data Pengetahuan, Sikap, Ketrampilan, dan Motivasi Belajar}

Hasil uji homogenitas data Pengetahuan menggunakan SPSS 16.0 for windows sehingga diperoleh hasil tabel Test Of Homogeneity Of Variances. Hasil data nilai Asymp.Sig. 0,956 yang nilainya lebih besar dari 0,05. Sehingga dapat disimpulkan bahwa data hasil belajar pengetahuan siswa dari kedua kelas tersebut homogen.

Hasil uji homogenitas data Sikap menggunakan SPSS 16.0 for windows sehingga diperoleh hasil tabel Test Of Homogeneity Of Variances. Berdasarkan data diperoleh bahwa nilai Asymp.Sig. 0,886 yang nilainya lebih besar dari 0,05. Sehingga dapat disimpulkan bahwa data hasil belajar sikap siswa dari kedua kelas tersebut homogen.

Hasil uji homogenitas data Ketrampilan menggunakan SPSS 16.0 for windows sehingga diperoleh hasil tabel Test Of Homogeneity Of Variances. Hasil data diperoleh hasil bahwa nilai Asymp.Sig. 0,691 yang nilainya lebih besar dari 0,05. Sehingga dapat disimpulkan bahwa data hasil belajar ketrampilan siswa dari kedua kelas tersebut homogen.

Hasil uji homogenitas data motivasi belajar menggunakan SPSS 16.0 for windows sehingga diperoleh hasil tabel Test Of Homogeneity Of Variances. Berdasarkan data diperoleh bahwa nilai nilai Asymp.Sig. 0,224 yang nilainya lebih besar dari 0,05. Sehingga dapat disimpulkan bahwa data hasil motivasi belajar siswa dari kedua kelas tersebut homogen.

\section{g. Analisis Data Hasil Belajar dan Motivasi Belajar}

Data yang diperoleh setelah diberikan perlakuan model pembelajaran Project Based Learning pada kelas eksperimen dan model pembelajaran kooperatif tipe Think Pair Share (TPS) pada kelas kontrol akan dianalisis hipotesis menggunakan uji-t dua pihak dengan prasyarat kedua data harus berdistribusi normal dan homogen. Uji hipotesis ini digunakan untuk mengetahui apakah terdapat perbedaan hasil belajar pengetahuan, sikap, keterampilan dan motivasi belajar pada kelas eksperimen dan kelas kontrol. il uji homogenitas data motivasi belajar menggunakan SPSS 16.0 for windows sehingga diperoleh hasil tabel Test Of Homogeneity Of Variances. Berdasarkan data diperoleh bahwa nilai nilai Asymp.Sig. 0,224 yang nilainya lebih besar dari 0,05. Sehingga dapat disimpulkan bahwa data hasil motivasi belajar siswa dari kedua kelas tersebut homogen.

\section{Analisis Data Sikap}

Uji statistik kesamaan dua rata-rata data Sikap menggunakan uji-t dua arah dengan bantuan SPSS 16.0 for windows melalui Independent Samples Test.

Berdasarkan data diperoleh bahwa hasil belajar siswa memiliki nilai Sig $<0,05=0,018<$ 0,05. Jadi H01 ditolak. Sehingga terdapat perbedaan yang signifikan pada hasil belajar 


\section{TEKNO Jurnal Teknologi, Elektro, dan Kejuruan}

http://journal2.um.ac.id/index.php/tekno | ISSN 1693-8739

ranah sikap menggunakan model pembelajaran Project Based Learning dan Think Pair Share (TPS) siswa jurusan teknik instalasi penerangan listrik SMKN 1 Blitar.

\section{Analisis Data Pengetahuan}

Uji statistik kesamaan dua rata-rata data Pengetahuan menggunakan uji-t dua arah dengan bantuan SPSS 16.0 for windows melalui Independent Samples Test. Berdasarkan data diperoleh bahwa hasil belajar siswa memiliki nilai Sig $>0,05=0,928>0,05$. Jadi H02 diterima. Sehingga tidak terdapat perbedaan yang signifikan pada hasil belajar ranah pengetahuan menggunakan model pembelajaran Project Based Learning dan Think Pair Share (TPS) siswa jurusan teknik instalasi penerangan listrik SMKN 1 Blitar.

\section{Analisis Data Ketrampilan}

Uji statistik kesamaan dua rata-rata data Ketrampilan menggunakan uji-t dua arah dengan bantuan SPSS 16.0 for windows melalui Independent Samples Test.

Berdasarkan data diperoleh bahwa hasil belajar siswa memiliki nilai Sig $<0,05=0,030<$ 0,05. Jadi H03 ditolak (Pratiwi, 2013). Sehingga terdapat perbedaan yang signifikan pada hasil belajar ranah ketrampilan menggunakan model pembelajaran Project Based Learning dan Think Pair Share (TPS) siswa jurusan teknik instalasi penerangan listrik SMKN 1 Blitar.

\section{Analisis Data Motivasi Belajar}

Berdasarkan data diperoleh bahwa hasil belajar siswa memiliki nilai Sig > 0,05 =0,558 > 0,05 . Jadi H04 diterima. Sehingga tidak terdapat perbedaan yang signifikan pada motivasi belajar menggunakan model pembelajaran Project Based Learning dan Think Pair Share (TPS) siswa jurusan teknik instalasi penerangan listrik SMKN 1 Blitar.

\section{Pembahasan}

Berdasarkan hasil penelitian Bab IV, dapat disimpulkan bahwa nilai belajar kelas eksperimen lebih tinggi daripada kelas kontrol. Hal ini ditunjukkan baik dari nilai Pengetahuan, nilai Sikap, dan nilai Ketrampilan.

Berdasarkan hasil perhitungan pada Bab IV bahwa antara dua kelas sama-sama terjadi peningkatan hasil belajar, tetapi peningkatan ini lebih didominasi oleh kelas eksperimen artinya hasil belajar kelompok eksperimen lebih baik jika dibandingkan dengan kelompok kontrol.

Dari analisis hasil belajar Pengetahuan siswa dengan uji independent sampel t-test didapatkan kesimpulan $\mathrm{H} 01$ diterima sehingga dapat disimpulkan bahwa tidak terdapat perbedaan yang signifikan pada hasil belajar ranah Pengetahuan menggunakan model pembelajaran Project Based Learning dan Think Pair Share (TPS) siswa jurusan teknik instalasi penerangan listrik SMKN 1 Blitar. Kemudian dari analisis hasil belajar Sikap siswa dengan uji independent sampel t-test didapatkan kesimpulan H02 ditolak, sehingga dapat disimpulkan bahwa terdapat perbedaan yang signifikan pada hasil belajar ranah Sikap menggunakan menggunakan model pembelajaran Project Based Learning dan Think Pair Share (TPS) siswa jurusan teknik instalasi penerangan listrik SMKN 1 Blitar. Selanjutnya 


\section{TEKNO Jurnal Teknologi, Elektro, dan Kejuruan}

http://journal2.um.ac.id/index.php/tekno | ISSN 1693-8739

dari analisis hasil belajar Ketrampilan siswa dengan uji independent sampel t-test didapatkan kesimpulan $\mathrm{H} 03$ ditolak, sehingga dapat disimpulkan bahwa terdapat perbedaan yang signifikan pada hasil belajar ranah Ketrampilan menggunakan menggunakan model pembelajaran Project Based Learning dan Think Pair Share (TPS) siswa jurusan teknik instalasi penerangan listrik SMKN 1 Blitar.

Model pembelajaran Project Based Learning melibatkan siswa secara langsung dalam pembelajaran, membantu siswa untuk mengajukan sebuah permasalahan atau tantangan dan bertanggung jawab secara kolaboratif untuk menentukan solusi atas permasalahan atau tantangan yang diajukan (Kurinasih, Imas dan Sani, Berlin. 2014). Siswa aktif dalam kegiatan pembelajaran, informasi dari guru digunakan untuk memecahkan masalah serta menjalin hubungan siswa dengan guru sebagai fasilitator karena guru tidak semata-mata memberikan informasi langsung namun sebagai fasilitator dalam membimbing dan menemukan pemecahan.

Perbedaan hasil belajar siswa disebabkan karena siswa yang diberi perlakuan dengan model pembelajaran Project Based Learning lebih antusias dan terdorong untuk mempelajari materi yang diberikan oleh guru dengan suatu project sebagai sumber utama dalam belajar. Siswa dilatih untuk menentukan project, menentukan jadwal kegiatan sampai mempertanggung jawabkan hasil project dengan anggota kelompoknya. Hal ini sesuai dengan pendapat (Kosasih, 2014) yang mengatakan bahwa karakteristik Project Based Learning memerlukan pendalaman terhadap materi utama sehingga siswa menemukan kebermaknaan dari materi tersebut dan keperluan yang dihadapi siswa dinyatakan dalam rumusan masalah yang menggambarkan suatu rancangan kegiatan yang dapat dilakukan siswa melalui proses pembelajaran serta siswa merancang kegiatan atau produk yang akan mereka hasilkan melalui perencanaan, proses kegiatan sampai pada produknya.

Berbeda dengan siswa kelas kontrol yang diberi perlakuan dengan menggunakan model pembelajaran Think Pair Share (TPS). Guru memberi materi Instalasi Penerangan Listrik Sederhana. Sebagian siswa masih kurang antusias dan kurang tertarik dalam kegiatan pembelajaran (Mulyasa, H.E. 2004). Hal ini menyebabkan siswa malas dalam mengerjakan setiap permasalahan yang diberikan oleh guru. Hal ini akhirnya berdampak pada nilai hasil belajar yang rendah. Model pembelajaran ini merupakan model pembelajaran berpikir berpasangan berbagi dengan tujuan untuk mempengaruhi pola interaksi siswa (Poerwati, L.E. dan Amri, S. 2013).

Dari penjelasan di atas, dapat disimpulkan bahwa hasil belajar pada materi menggambar dan merancang serta memasang instalasi penerangan listrik sederhana dengan model pembelajaran Project Based Learning lebih baik daripada menggunakan model pembelajaran Think Pair Share, karena siswa yang diberi perlakuan dengan menggunakan model pembelajaran Project Based Learning siswa dapat lebih mendalami materi dan lebih banyak mendapatkan pengalaman dari project yang mereka tentukan 


\section{TEKNO Jumal Teknologi, Eektro, dan Kejuruan}

http://journal2.um.ac.id/index.php/tekno | ISSN 1693-8739

sendiri dan harus dapat mempertanggungjawabkan hasil project yang mereka buat. Selain itu, mereka juga mendapatkan arahan dan bimbingan dari guru dalam menyelesaikan masalah.

Sedangkan Berdasarkan hasil penelitian Bab IV, dapat disimpulkan bahwa nilai motivasi belajar kelas eksperimen lebih tinggi daripada kelas kontrol.

Berdasarkan hasil perhitungan pada Bab IV bahwa antara dua kelas sama-sama terjadi peningkatan hasil motivasi belajar, tetapi peningkatan ini lebih didominasi oleh kelas eksperimen artinya hasil motivasi belajar kelompok eksperimen lebih baik jika dibandingkan dengan kelompok kontrol. Perbedaan nilai rata-rata hasil motivasi belajar siswa kelas eksperimen dan kelas kontrol sangat kecil yaitu sebesar 1,03. Jadi peningkatan hasil motivasi belajar siswa sangat kecil.

Dari analisis hasil belajar Pengetahuan siswa dengan uji independent sampel t-test didapatkan kesimpulan $\mathrm{HO}$ diterima, sehingga dapat disimpulkan bahwa tidak terdapat perbedaan yang signifikan pada motivasi belajar menggunakan model pembelajaran Project Based Learning dan Think Pair Share (TPS) siswa jurusan teknik instalasi penerangan listrik SMKN 1 Blitar.

Perbedaan hasil motivasi belajar siswa disebabkan karena siswa yang diberi perlakuan menggunakan model pembelajaran project Based Learning lebih terdorong dan merasa tertarik dengan materi yang sudah dibahas. Selain itu siswa lebih antusias dengan adanya project yang mereka buat. Siswa akan terus berusaha menyelesaikan masalah yang mereka jumpai selama proses penyelsaian project. Sehingga siswa merasa proses pembelajaran tidak membosankan. Selain itu siswa dilatih untuk bisa bertukar pendapat dengan teman dan akan membangkitkan keaktifan belajar. Motivasi sebagai sejumlah proses yang bersifat internal atau eksternal bagi seorang individu yang menyebabkan timbulnya sikap antusiasme dan presistensi dalam hal melaksanakan kegiatan-kegiatan tertentu (Abdul Majid, 2013). Selain itu dalam proses pembelajaran guru memberikan pujian kepada siswa yang dapat menginterprestasikan hasil diskusi dengan jawaban yang tepat dan benar (Suparno, 2007). Hal tersebut meningkatkan motivasi belajar siswa untuk berkompetisi dan keinginan mencapaicita-cita kejenjang yang lebih tinggi. Sesuai pernyataan diatas Sardiman (2011:92) berpendapat bahwa ada sebelas bentuk serta cara membentuk motivasi di sekolah,yaitu: (1) memberi angka; (2) hadiah; (3) saingan/kompetisi; (4) ego-involvement; (5) memberi ulangan; (6) mengetahui hasil; (7) pujian; (8) hukuman; (9) hasrat untuk belajar; (10) minat; (11) tujuan yang diakui.

Berbeda dengan siswa kelas kontrol yang diberi perlakuan dengan menggunakan model pembelajaran Think Pair Share (TPS). Siswa kurang antusias dengan materi instalasi penerangan listrik sederhana yang dipelajari. Respon siswa terhadap model pembelajaran Think Pair Share (TPS) rendah. Hal ini menjadikan siswa kurang termotivasi selama proses pembelajaran. Akibatnya berdampak pada hasil belajar siswa yang menjadi lebih rendah daripada kelas eksperimen. 


\section{TEKNO Jurnal Teknologi, Elektro, dan Kejuruan}

http://journal2.um.ac.id/index.php/tekno | ISSN 1693-8739

Dari penjelasan di atas, dapat disimpulkan bahwa hasil motivasi belajar pada materi menggambar dan merancang serta memasang instalasi penerangan listrik sederhana dengan model pembelajaran Project Based Learning lebih baik daripada menggunakan model pembelajaran Think Pair Share, karena siswa lebih tertarik dalam membuat project sesuai dengan perencanaan siswa itu sendiri dan pembelajaran menjadi tidak membosankan.

\section{Kesimpulan}

Berdasarkan hasil penelitian dan analisis data dapat diperoleh kesaimpulan sebagai berikut:

1. Hasil belajar ranah Sikap diketahui terdapat perbedaan yang signifikan menggunakan model pembelajaran Project Based Learning dan Think Pair Share (TPS) berbantuan modul ajar pada mata pelajaran kompetensi kejuruan SMKN 1 Blitar.

2. Hasil belajar ranah Pengetahuan diketahui tidak terdapat perbedaan yang signifikan menggunakan model pembelajaran Project Based Learning dan Think Pair Share (TPS) berbantuan modul ajar siswa pada mata pelajaran kompetensi kejuruan SMKN 1 Blitar.

3. Hasil belajar ranah Ketrampilan diketahui terdapat perbedaan yang signifikan menggunakan model pembelajaran Project Based Learning dan Think Pair Share (TPS) berbantuan modul ajar pada mata pelajaran kompetensi kejuruan SMKN 1 Blitar.

4. Hasil motivasi belajar diketahui tidak terdapat perbedaan yang signifikan menggunakan model pembelajaran Project Based Learning dan Think Pair Share (TPS) berbantuan modul ajar siswa pada mata pelajaran kompetensi kejuruan SMKN 1 Blitar.

\section{Saran}

Berdasarkan hasil penelitian, ada beberapa saran yang dapat disampaikan oleh penulis sebagai berikut:

1. Pembelajaran dengan model Project Based Learning bersifat efektif dan baik diterapkan disekolah untuk matapelajaran yang berbasis proyek serta baik diterapkan dikelas jika masing-masing peserta didik memiliki sifat aktif dalam mencari informasi. Pada model Project Based Learning pembelajaran dapat berlangsung dengan lancar jika semua peralatan dalam kegiatan penyelesaian proyek yang ada disekolah lengkap dan memadai.

2. Model pembelajaran Think Pair Share (TPS) sebaiknya diterapkan lebih mendalam didalam proses pembelajaran jika pendidik dapat memonitor atau mengawasi peserta didik dalam jumlah kelompok yang banyak.

3. Penggunaan model Project Based Learning dan Think Pair Share (TPS) dapat menambah pengetahuan, mengembangkan kemampuan guru utamanya dalam pembelajaran pada ranah ketrampilan, atau pembelajaran berbasis praktikum. 


\section{TEKNO Jurnal Teknologi, Elektro, dan Kejuruan}

http://journal2.um.ac.id/index.php/tekno | ISSN 1693-8739

\section{Daftar Rujukan}

Abidin, Yunus. 2014. Desain Sistem Pembelajaran Dalam Konteks Kurikulum 2013. Bandung: PT. Refika Aditama.

Arikunto, Suharsimi. 2009. Dasar-dasar Evaluasi Pendidikan (Edisi Revisi). Jakarta: Bumi Aksara.

BSNP. 2006. Panduan Penyusunan Kurikulum Tingkat Satuan Pendidikan Jenjang Pendidikan Dasar dan Menengah. Jakarta: Badan Standar Nasional Pendidikan.

Dimyati dan Mudjiono. 2009. Belajar dan Pembelajaran. Jakarta: Rineka Cipta.

Hamalik, Oemar. 2014. Psikologi Belajar dan Mengajar. Bandung: Sinar Baru Algensindo.

Kosasih, E. 2014. Startegi Belajar Dan Pembelajaran Implemenrtasi Kurikulum 2013. Bandung: Yrama Widya.

Kurinasih, Imas dan Sani, Berlin. 2014. Implementasi Kurikulum 2013: Konsep \& Penerapan. Surabaya: Kata Pena.

Lia, Nur E. R. W. 2013. Perbedaan Prestasi Belajar Antara Model Pembelajaran Project Based Learning (PBL) dengan Kooperatif Think Pair Share (TPS) Pada Matapelajaran Pemrogramman Dasar Kelas X di SMK Negeri 2 Singosari. Malang: FT. Universitas Negeri Malang.

Majid, Abdul. 2013. Strategi Pembelajaran. Bandung: PT. Remaja Rosdakarya Offset.

Mulyasa, H.E. 2004. Kurikulum Berbasis Kompetensi. Bandung: Remaja Rosdakarya Offset.

Poerwati, L.E. dan Amri, S. 2013. Panduan Memahami Kurikulum 2013. Jakarta: PT. Prestasi Pustaka.

Pratiwi, Indah S. 2013. Perbedaan Hasil Belajar dan Metakognitif Siswa SMK Matapelajaran Pemrograman Web Menggunakan Project Based Learning dan Think Pair Share. Malang: FT. Universitas Negeri Malang.

Priyatno, Duwi. 2012. Belajar Cepat Olah Data Statistik dengan SPSS. Yogyakarta: C.V Andi Offset.

Rais, Muh. 2010. Project-Based Learning Inovasi Pembelajaran yang Berorientasi Soft Skills. Makassar.

Riyanto, Yatim. 2010. Paradigma Baru Pembelajaran sebagai Referensi bagi Pendidik dalam Implementasi Pembelajaran yang Efektif dan Berkualitas. Jakarta: Kencana Prenada Mitra Group.

Sanjaya, Wina. 2013. Strategi Pembelajaran Berorientasi Standar Proses Pendidikan. Jakarta: Kencana Prenadamedia Group.

Sardiman, A. M. 2011. Interaksi \& Motivasi Belajar Mengajar. Jakarta: Rajawali Pers.

Sudjana, Nana. 2013. Penilaian Hasil Proses Belajar Mengajar. Bandung: PT Remaja Rosdakarya.

Sugiyono. 2013. Metode Penelitian Pendidikan (Pendekatan Kuantitatif, Kualitatif, dan R\&D). Bandung: Alfabeta. 
TEKNO Jurnal Teknologi, Elektro, dan Kejuruan

http://journal2.um.ac.id/index.php/tekno | ISSN 1693-8739

Suparno, Erman. 2007. Keputusan Menteri Tenaga Kerja dan Transmigrasi Republik Indonesia. Jakarta.

Syah, Muhibbin. 2013. Psikologi Pendidikan Dengan Pendekatan Baru. Bandung: PT Remaja Rosdakarya Offset.

Trianto. 2011. Model-Model Pembelajaran Inovatif Berorientasi Konstruktivistik. Jakarta: Prestasi Pustaka. 